\title{
Regulator-led Resolution in Mass Finance Mis-selling: Implication of the UK PPI Scandal
}

\author{
Young Yoon Park
}

The resolution process of PPI scandal was led and driven by the UK's FCA-financial regulator based on powers stipulated in Financial Services and Markets Act 2000. FCA made rules requiring financial institutions concerned to assess mis-selling claims of PPI holders and pay redress to them if mis-selling was found. The opt-out class action, in contrast, is not likely to handle finance mis-selling collectively because commonality requirement is not easily satisfied. The PPI resolution process overcame this problem by assigning the investigation and assessment of individual aspects of the disputes to the financial institutions concerned. This approach is equitable in that financial institutions which are liable to the scandal bears the time and pecuniary cost instead of relying on public resources of courts as in the litigation. The regulator-led resolution can be helpful in designing collective resolution system of finance mis-selling which is characterized as mass victims with small damages.

\section{Keywords}

Payment Protection Insurance, Mis-selling, Suitability, Consumer Redress Scheme, Class Action, Mass Torts

* Attorney-at-Law (Korean Bar) practicing at Yulchon LLC. B.A./M.A. in Economics (Seoul N.U.), J.D. (magna cum laude, Yonsei), LL.M. (King's College London). ORCID: https://orcid.org/0000-0003-4443-1622. The author may be contacted at: yypark@yulchon.com / Address: Parnas Tower, 38th Floor, 521 Teheran-ro, Gangnam-gu, Seoul 06164 Korea. This paper was fully revised and updated version of the author's thesis for master of laws degree titled, "Applicability of Regulatory Intervention as Efficient Way of Collective Redress to Korea - Review on the UK PPI Case" submitted to King's College London (2019). All the websites cited in this article were last visited on November 15, 2019. 


\section{Introduction}

Mis-selling of securities, financial instruments or insurance is one of the main topics in financial regulation irrespective of jurisdictions. The resolution process of Payment Protection Insurance ("PPI") disputes in the UK provides implications in this area. PPI is an insurance product in which insurers pay insurance benefit to borrowers when they are not able to repay the debt due to sickness, injury, unwanted unemployment, etc. PPI has been sold widely in the context of various types of borrowings for several decades as support to creditworthiness of borrowers. " "The premiums may be paid regularly or as a single premium."

Various kinds of mis-selling have been reported since early 2000's. PPIs were sold without checking consumers' demands and needs. All relevant information of PPI including range of insurance cover and costs were not explained to consumers in good time. Consumers were pressed to buy PPI with insufficient knowledge about it. They often believed that PPI was a condition for getting approval for lending even though it was not true. In cases where PPI sellers were introduced to customers by brokers, the existence and amount of commission were not disclosed to those customers even when the level of commission was excessive. Consequently, many of consumers bought PPI without establishing a need for it. ${ }^{3}$

PPI can be sold only when consumers consider borrowing money. As consumers tend to concentrate on the main contract, (the borrowing agreement), PPI, a kind of incidental product, seems to be less carefully considered. For this reason, PPI has an inherent risk of being mis-sold in the first place. Many consumers were not sure if they held PPI in extreme cases and an advertising campaign by the Financial Conduct Authority ("FCA") had to focus on reaching those consumers.

Most notably, the relief on PPI mis-selling was led and driven by the regulator's intervention. As the mis-selling practice was so broad to the industry and the number of victims were so large, the FCA and its predecessor, the Financial Services Authority ("FSA"), which took the regulatory role during the scandal, devoted much of its resources to addressing the scandal. It was argued, after the fact, that FSA's

1 Fin. Conduct Auth., Consultation Paper 15/39: Rules and Guidance on Payment Protection Insurance Complaints, 2015, $\uparrow 1.23$ (UK).

2 Brit. Bankers Ass'n, v. Fin. Serv. Auth. \& Fin. Ombudsman Serv. [2011] EWHC 999 (Admin) 1.

3 Fin. Serv. Auth., Final Notice to Swinton Group, 2009, 2.6; Plevin v. Paragon Pers. Fin. Ltd. \& Another [2012] EW Misc. 24; Fin. Conduct Auth., Handbook Disp App., 2010, at 3.6.2 (UK).

4 Plevin, EW Misc 24; Fin. Conduct Auth., Policy Statement 17/03: Payment Protection Insurance Complaint: Feedback on 16/20 and Final Rules and Guidance, 2017, 93.11 (UK). 
failure to cope with the bankruptcy of Northern Rock in the global financial crisis in 2007 was attributable to an overall location of regulatory resources toward the PPI scandal. ${ }^{5}$ Based on recent FCA statistics, financial institutions handled over 18.4 million PPI complaints and the redress amount paid is over 26 billion pounds. ${ }^{6}$

The primary purpose of this research is to introduce the regulator-led collective relief process relating to the PPI scandal and review its applicability to other jurisdictions. This paper is composed of five parts including Introduction and Conclusion. Part two will explain the collective dispute resolution process on PPI scandal. Part three will analyze the possibility of using opt-out class action to settle PPI scandal. Part four will examine the practices in other jurisdictions regarding the application of regulatory intervention.

\section{Collective Dispute Resolution Process on PPI Scandal}

\section{A. Powers of FCA}

As the UK finance regulator, the FCA (including its predecessor FSA) has broad and extensive regulatory powers. It has a general rule-making power on regulated activities granted by Section 137A et seq. of the FSMA. The FCA has published a handbook based on that power covering business standards of financial institutions. The Insurance Conduct of Business Standard ("ICOBS") is part of that handbook. This power seems stronger than that of counterparties in Civil Law jurisdictions where the regulator's power is subject to strict delegations stipulated in parliamentary legislation.

The FCA's role is not limited to preventive and disciplinary actions on financial institutions' conduct but extends to damages or restitutions. The FCA may apply to the court for an order that the person having contravened a "relevant requirement" should pay redress to the aggrieved parties. ${ }^{7}$ As far as the contravention of authorized persons who are main focus of FCA regulation are concerned, the FCA may require them to pay redress to the aggrieved consumers without application to court. ${ }^{8}$ These two powers envisage redress to multiple consumers rather than to specific or limited

5 E. Ferran, Regulatory Lessons from the Payment Protection Insurance Mis-selling Scandal in the U.K., 13 EuR. Bus. Org. L. Rev. 248 (2012).

6 Fin. Conduct Auth., supra note 4, $₫ 1.2$.

7 Financial Services and Markets Act 2000, c. 8, §382(UK).

$8 \quad$ Id. $\$ 384$. 
ones. ${ }^{9}$ This seems natural, considering that the FCA acts as public body in relation to this power, not as a private party, even when the provision is civil in its nature.

The most outstanding point among the FCA's powers is its "consumer redress scheme" provided in Section 404 of FSMA. Under this provision, the FCA has the power to make "consumer redress scheme" as its own rule in case of widespread or regular failure by authorized persons to comply with proper requirements. This can be understood as an extension of FCA's general rule-making power. Under the scheme, the relevant firm must: (1) "first investigate whether it has failed to comply with the requirements"; (2) "determine whether the failure has caused (or may cause) loss or damage to consumers"; (3) "determine what the redress should be in respect of the failure"; and (4) "make the redress to the consumers" on such decisions. ${ }^{10}$ Hence, under the scheme, identification of aggrieved consumers, investigation of mis-selling cases, setting up of specific redress plans, and payment to identified victims should be all performed by financial institutions.

Financial consumers can appeal to the Financial Ombudsman Service ("FOS") if they are "not satisfied with a redress determination made by a respondent [financial institution] under a consumer redress scheme" or "consider that a respondent has failed to make a redress determination in accordance with a consumer redress scheme"11 within six months after the date of receipt of consumer redress determination. ${ }^{12}$ FOS is designed to settle disputes "quickly and with minimum formality." possible stage" and by the "most appropriate" means. ${ }^{14}$ The Ombudsman may determine "without convening a hearing" if $\mathrm{s} /$ he decides it is appropriate ${ }^{15}$ and apply a different standard on inclusion of evidence. ${ }^{16}$ Meanwhile, financial institutions may challenge the FCA rules on consumer redress scheme before the Tribunal. ${ }^{17}$

9 This is evident from wording of the provision. FSMA $\$ 382(3)$ states: "[a]ny amount paid to the regulator concerned in pursuance of an order under subsection (2) must be paid by it to such qualifying person or distributed by it among such qualifying persons as the court may direct." Likewise, \$382(5) provides that "the power referred to in subsections (1) and (2) is a power to require the person concerned, ... to pay to the appropriate person or distribute among the appropriate persons such amount."

10 Supra note 7, §404(3)-(7).

11 Fin. Conduct Auth. Handbook Disp. 2011, at 2.3.2C (UK).

12 Id. at 2.8.2.

13 Supra note $7, \S 225$.

14 Supra note 11, at 3.5.1.

15 Id. at 3.5.5.

16 Id. at 3.5.9.

17 Supra note 7, §404D. 


\section{B. The First Stage of PPI Resolution Process}

The dispute resolution of PPI scandal has mainly relied on FCA regulatory power explained before. As provided by FSA's Policy Statement 10/12 titled, "The Assessment and Redress of Payment Protection Insurance Complaints" ("PS 10/12") on August 10, 2010, ${ }^{18}$ FSA tried at first to rely on cooperation with the industry on the basis of the "Treating Customers Fairly initiative" as far as consumer redress is concerned. ${ }^{19}$ However, the settlement process was very slow and FSA' ongoing investigation showed PPI mis-selling was more widespread than originally thought. ${ }^{20}$ The FSA found that 'firms' rejection rates remained high, and their 'overturns' at the FOS likewise remained high." 21 This could be interpreted as signaling that the finance industry and the regulator had different views on what is an acceptable way of handling PPI sales.

The use of regulatory power commenced under this situation. PS 10/12 was published dealing with the principles of redress which should be taken by financial institutions. It included "but for test," which meant companies would be liable for mis-selling if that consumers would not have bought PPI without weaknesses suggested in the statement. ${ }^{22}$

FSA clarified that the PS 10/12 was based on the general rule-making power in Section 137 et seq., ${ }^{23}$ while the whole scheme seemed to be intended to have similar effects to consumer redress scheme of Section 404. This was mainly because the Section 404 could be applied only to non-compliance of specific 'rules' at the time of PPI mis-selling. ${ }^{24}$ Although FSA tried to apply Principles for determining the liability of a financial institution, it was impossible under the previous wording of Section 404 of FSMA. FCA explained, in relation to settlement of Plevin issue, that "[g]iven that we did not require commission disclosure in our ICOB/ICOBS rules, it would be inappropriate to require (e.g. under a s.404 scheme) to proactively review" ${ }^{25}$ all of the

18 Fin. Serv. Auth., Policy Statement 10/12: The Assessment and Redress of Payment Protection Insurance Complaints, 2010, 1 1.6, available at https://www.fca.org.uk/publication/policy/ps10_12.pdf.

19 A. Georgosouli, Payment Protection Insurance (PPI) Misselling: Some Lessons from the UK, 21 ConN. Ins. L. J. 263 (2014).

20 Id. at 263.

21 Supra note 18, at 92.11 (21)-(22).

22 Supra note 18, ๆๆ 3.14, 3.21, app. ๆ 3.6.

23 Section A, appendix of PS 10/12 explained that the rule regarding PPI settlement was based on the powers given by "section 138 (General rule-making power); (2) section 149 (Evidential provisions); and (3) section 157(1) (Guidance)."

24 Supra note 2, at 191.

25 Supra note 4, ๆ 3.30, available at http://www.fca.org.uk/publications/policy-statements/ps17-3-payment-protectioninsurance-complaints. 
past selling cases.

Financial institutions, under the PS 10/12, are required to investigate only complaints brought by consumers, while investigation on all past selling cases is required under Section 404. Instead, FCA made a large-scale campaign to inform consumers of the resolution scheme and to urge them to claim to sellers if mis-selling was doubted. Consequently, the process dealing with huge volumes of mis-selling cases, as a whole, does not look much distant from that envisaged by the consumer redress scheme in Section 404.

\section{Court Ruling on British Bankers Association Case}

The British Bankers' Association ("BBA") challenged the legality of PS 10/12. BBA's main argument was that the FSA was trying to impose liability based on Principles even though the rules in ICOBS had been complied. Here, the Principles contain rather fundamental and abstract obligations that should be complied with by authorized persons, while rules address more concrete and prescriptive norms. In relation to this point, BBA pointed out that Section 138D of FSMA permitted financial consumers to bring civil remedy actions only for breach of rules. ${ }^{26}$ Hence, according to BBA, PS 10/12, by applying Principles to determine liability, augmented or distorted the scope of both financial institutions' obligations and consumers' actionability which are stipulated in the FSMA. ${ }^{27}$

However, the High Court concluded that Section 138D of FSMA was just a requirement for civil actions brought before the court, which was not applied on FOS procedures or FCA's rule-making power. Based on the judgment, actionability did not mean that only a breach of rules could sound in remedies. ${ }^{28}$ Furthermore, the High Court held that rules were not exhaustive of what financial institutions should comply in PPI sales. Principles are overarching framework for regulation and provides contents on rules. Hence, the BBA's argument that Principles could augment or distort rules was wrong in itself. ${ }^{29}$

In addition, a doubt was brought on whether it was legal for FSA to rely on general rule-making power in Section 137 et seq. instead of Section 404 of FSMA, as a means to handle PPI saga. This argument was based on a typical division that the former related to preventive measures, while the latter was an ex-post response to 
"wide or regular failure." The High Court concluded that there was no ground that the regulatory means to intervene "widespread or regular failure" in PPI should be limited to Section 404. Rather, the Court decided that the regulator could rely on general rule-making power as well. ${ }^{30}$

This judgment approved the FSA's PS 10/12 regarding the use of Principles and general-rule making power in both substantive and procedural aspect, respectively.

\section{Court Ruling on Plevin Case and the Second Stage of PPI Resolution Process}

In Plevin case, the UK Supreme Court decided, reversing the previous Court of Appeal precedents, ${ }^{31}$ that the excessive brokerage commission paid by consumers gave rise to an "unfair relationship" within the meaning of Section 140A of Consumer Credit Act of 1974 if such commission was not disclosed. ${ }^{32}$

ICOBS rules did not require disclosure of commission. Based on the Supreme Court's decision, however, the ICOBS rules are not an essential determinant of fairness, but only minimum standard for judging fairness of lender-debtor relationship. The Court decided:

[a] sufficiently extreme inequality of knowledge and understanding is a classic source of unfairness in any relationship between a creditor and a non-commercial debtor. It is a question of degree. ... Mrs Plevin's evidence ... was that if she had known that $71.8 \%$ of the premium would be paid out in commissions, she would have certainly questioned this. ${ }^{33}$

This case law led the FCA to a new rule for collective relief in "Policy Statement 17/03: Payment Protection Insurance Compliant" ("PS 17/03"). ${ }^{34}$ FCA, once again based on general rule-making power, required financial institutions to investigate customer's claims and pay redress if Plevin issue was found. Especially, consumers were given another opportunity to claim redress under PS 17/3 even though their claims had been dismissed before, as long as their claim was related to Plevin issue. ${ }^{35}$ With the expiry of deadline, August 2019 set by the FCA, PPI settlement process

$30 \quad$ Id. at $248-63$.

31 Harrison \& Another v. Basic Horse Ltd. [2011] EWCA Civ. 1128.

32 Plevin (Respondent) v Paragon Pers. Fin. Ltd. (Appellant) [2014] UKSC 61.

33 Id. at 18.

34 Fin. Conduct Auth., supra note 4, ๆ 2.1.

35 Id. $ๆ 2.13$. 
finally ended.

\section{E. Salient Characteristics of the PPI Resolution Process}

Some points are noteworthy in the PPI relief process. First, the civil relief process was led and driven by the regulator, ${ }^{36}$ while the court's role was limited to approving or promoting the regulator's action. This is in contrast with many of other jurisdictions where the regulator's role is limited to disciplinary action and civil disputes are handled in courts.

Second, the FSA and FCA exercised wider discretion on the resolution of scandal. The regulator could select proper measures among its' diverse powers granted by the FSMA and assemble them in response to specific problems. ${ }^{37}$ Principle based remedy also inevitably entailed exercise of regulator's discretion.

Third, the financial regulator's discretion has focused on consumer protection. In particular, the regulator itself made a campaign to explain the redress procedure to consumers, which made consumer relief more accessible. The FCA tried to approach those who did not know even they held PPI and the FCA's campaign broadcast focused on urging consumers to check if they were PPI holders. ${ }^{38}$

Finally, the process successfully handled both collective and individual nature of dispute by separating them. The collective nature was found in application of uniform standard prepared by the FCA. For instance, PS $17 / 3$ sets a prima facie uniform standard of unfairness - 50 percent. In other words, if brokerage commission had occupied more than half of the total amount paid by consumers which had not

36 The regulator also took the measures correcting for structural approach as part of dealing with the saga. FSA made an industry-wide agreement on stopping single premium PPI. See supra note 8, 1 1.6. Another regulator, Competition Authority (Competition Market Authority currently, Competition Committee at the time of intervention) exercised its power to perform market investigation. This power focuses on market structure and environment from the perspectives of consumer welfare rather than infringements of the Competition Act (Section 5 of the Enterprise Act 2002). The competition authority can make decisions for remedying those problems confirmed by market investigation. Competition Committee, based on the market investigation on PPI, recognized that consumers were hindered from comparing diverse kinds of PPI products. Especially, according to Competition Committee, consumers were restricted in getting access to information on the product provided by others than the lender they were contacting. Competition Committee concluded that this weakness hindered competition among PPI providers and, as a result, undermined the consumer welfare. The competition authority prohibited stand-alone PPI (whose premium is paid one time at the time of making contract rather than pay-as-you-go way) and required firms concerned to provide more information about personal PPI quote or third-party provider. See also Payment Protection Insurance Market Investigation Order 2011 (UK), available at https://assets.publishing.service.gov.uk/government/uploads/system/uploads/attachment_data/ file/330608/ppi_order.pdf.

37 FSA selected its general rule-making power to cope with PPI saga instead of consumer collective redress scheme under Section 404, and this approach was approved by the Court in BBA case.

38 Supra note $18, \boldsymbol{\Upsilon} 2.11$, at 22-3. 
been disclosed at the time of selling PPI, financial institutions were required to pay the part over 50 percent by PS 17/3. ${ }^{39}$ Setting up uniform standards is inevitable in order to deal with huge number of cases in a rapid and efficient way, which is also frequently found in opt-out class actions. ${ }^{40}$ However, the specific facts constituting individual nature of the disputes were investigated by financial institutions by regulator-made rules. The division of roles appears to be the strong point in PPI resolution process.

\section{Possibility of Using Opt-Out Class Action as a Means to Settle PPI Scandals}

\section{A. A Strict Criterion on Commonality under the US Rule}

The US style opt-out class action, which is taken as the most typical approach to collective redress, goes on two stages-certification and merit stage, and merits can be assessed only when the case passes the certification stage. The Section 23 of the US Federal Rules of Civil Procedure ("FRCP”) requires that: “... (2) there are questions of law or fact common to the class ..." as one of the requirements for certification. FRCP Section 23(b)(2) further requires that: “... the questions of law or fact common to class members [should] predominate over any questions affecting only individual members" as to damages claim.

Wal-Mart's case shows how these requirements work. Representative claimants maintained that female workers in Wal-Mart were discriminated in promotion and salaries based on gender. Representative claimants mainly argued that storemanagers had discriminated female workers in recommending candidates for promotion evaluation. Hence, based on the argument, Wal-Mart was liable for the damages because they permitted discretion to managers, thereby causing discrimination against female workers in promotion. ${ }^{41}$

However, the US Supreme Court denied the certification of opt-out class action. The Court held that: "The conceptual gap between an individualt's discrimination claim and the existence of a class of persons who have suffered the same injury, ... must

39 Fin. Conduct Auth., supra note 3, at 3.7A.3A. This appendix was inserted into the Handbook by PS 17/3.

40 In opt-out class action also, damages are calculated based on an identical formula or statistical method which is applied to all class members in the same way. See E. Sherman, Group Litigation under Foreign Legal Systems: Variations and Alternatives to American Actions, 52 DePAUL L. Rev. 409 (2002).

41 Wal-Mart Stores, Inc. v. Dukes, 131 S.Ct. 2541 (2011). 
be bridged by significant proof that an employer operated under a general policy of discrimination. ${ }^{\prime 2}$ The representative claimants neither argued nor proved that Walmart itself implemented a firm-wide policy towards discriminating against female workers. Issues on exercise of discretion meant that each promotion assessment should be judged individually based on specific facts, which hinders commonality and predominance from being satisfied. The US Supreme Court provided, on this point, that: "[w] hat matters to class certification is not the raising of common questions, even in droves, but rather the capacity of class-wide proceeding to generate common answers apt to drive resolution of litigation."

Similar reasoning is taken in regard to insurance benefit payments. In Basurco's case, for instance, the defendant insurance company refused payment of an insurance benefit to home-owners on the ground that their claims on benefit had not been made within one year from the earthquake as required by subscription agreement. ${ }^{44}$ The representative claimant argued that the agreement provision on deadline is invalid due to unfairness, etc., but the Appellate Court of California did not review such argument. ${ }^{45}$ Instead, the Court held that whether the impairment of property was caused by earthquake, one essential part of assessing liability, should be judged based on individual investigation. ${ }^{46}$ For this reason, the Court denied certification.

The requirements of commonality and predominance are naturally a great hurdle to mis-selling cases, as well. In order for mis-selling of financial instruments to be established, the following facts should be satisfied: (1) the seller's deceitful or negligent conduct; (2) subject element of the seller such as scienter; ${ }^{47}$ (3) the buyer's reliance on mis-selling behavior; (4) economic loss; and (5) loss causation. Hence, to handle mis-selling in class-action, common legal and factual issues should predominate individual issues in relation to all of these five elements, respectively. ${ }^{48}$

However, the first element-deceit or negligence in sale process-is hard to meet commonality and predominance. For instance, only a few insurance subscribers might have been told deceitful explanations. Suitability test might have been taken

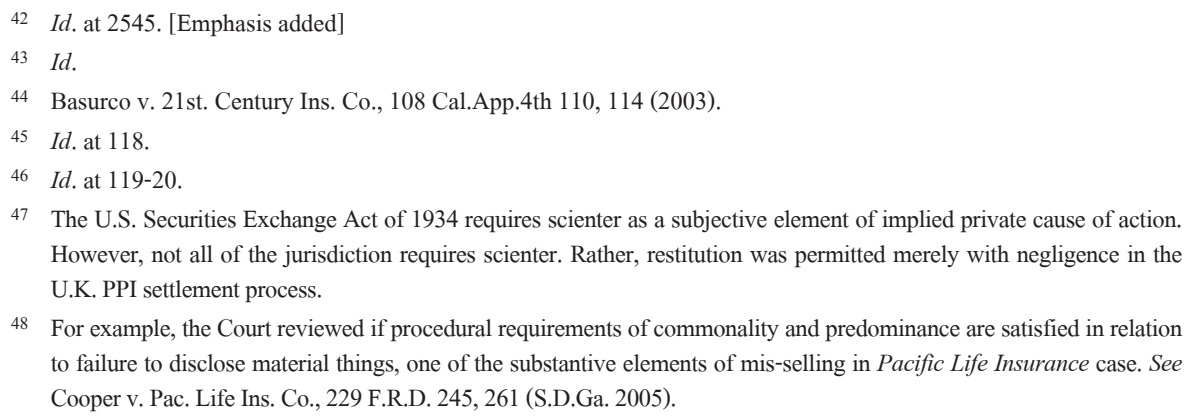

48 For example, the Court reviewed if procedural requirements of commonality and predominance are satisfied in relation to failure to disclose material things, one of the substantive elements of mis-selling in Pacific Life Insurance case. See Cooper v. Pac. Life Ins. Co., 229 F.R.D. 245, 261 (S.D.Ga. 2005). 
only to some investors selectively, while others not. Hence, specific facts relating to each selling process should be assessed on individual base. This is the reason why class action is not easily permitted in mis-selling cases.

An exception is only found where deceit was acknowledged in prospectuses (Pacific Life Insurance case $^{49}$ ) or brochures (Yokoyama case ${ }^{50}$ ). As these documents were distributed to all buyers and oral explanations also followed the documents, the material misrepresentation in them could constitute major common issue. In more typical mis-selling cases, however, a documented prospectus tends to include proper caveats regarding investment risk and other adverse things even though they are a simple formality. The really problematic part is on oral explanation given to consumers, which requires investigation on individual face-to-face selling process. ${ }^{51}$

Another difficulty may be found in reliance element. The difficulty also arises as to misrepresentation case (not only in mis-selling case), because not all members of a group cannot be said to rely on securities issuer's misrepresentation in their investment decision-making. The US Supreme Court overcame this issue by introducing so-called fraud-on-market theory established in Basic v. Levinson case in 1988. ${ }^{52}$ This approach, which is in turn based on efficient market hypothesis, takes the view that "material misrepresentation or omission" in disclosure is reflected in the share price, which operates as basis for investment decision-making and, accordingly, the investors who invested in a certain securities with a belief that the market price of the security is true are deceived indirectly by material misrepresentation. ${ }^{53}$

Based on this approach, "plaintiff may invoke rebuttable presumption of reliance, rather than proving direct reliance on a misrepresentation, by demonstrating that: (1) alleged misrepresentations were publicly known; (2) they were material; (3) the stock traded in efficient market; and (4) plaintiff traded the stock between time the misrepresentations were made and when the truth was revealed." ${ }^{\text {"54 }}$ The 'materiality' is assessed based on a reasonable investor and by objective criteria. ${ }^{55}$ Following fraud-on-market theory, subjective and individual factors are substituted by objective

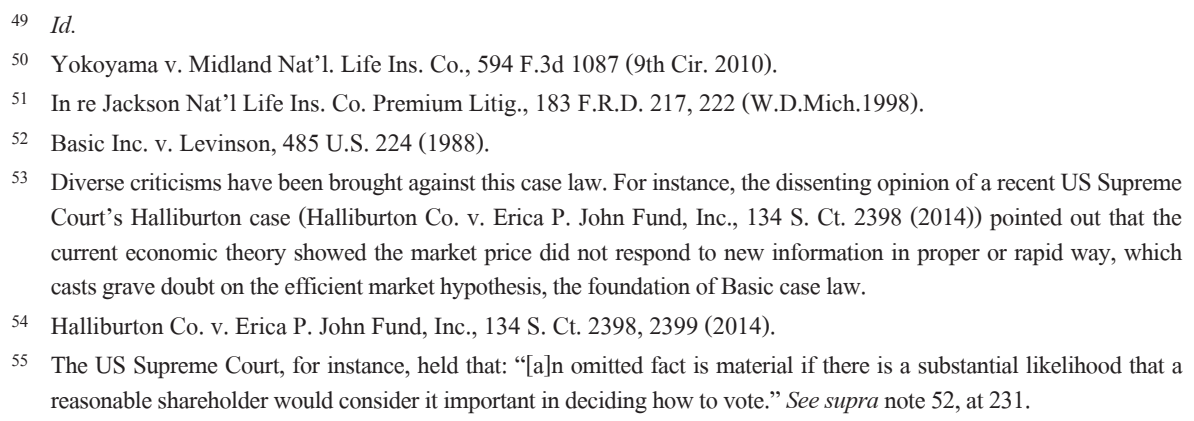

55 The US Supreme Court, for instance, held that: "[a]n omitted fact is material if there is a substantial likelihood that a reasonable shareholder would consider it important in deciding how to vote." See supra note 52, at 231. 
criteria which could be applied commonly to all investors. This conversion promoted an explosion of misrepresentation class-actions in America. ${ }^{56}$

This conversion is based on the premise that all investors believe that the market price is genuine, which is relatively easily accepted based on common sense. ${ }^{57}$ However, in mis-selling case, investors not only face the different disclosure by sellers as aforementioned, but also accept and respond to the given information in their own different ways. Accordingly, even if a certain mis-selling practice was conducted identically to all members of a class, it does not necessarily mean that a class action is justified. For instance, if a group member equipped with sufficient knowledge and experience in finance can spot problems in the wrong explanation, s/he can avoid being defrauded. ${ }^{58}$ This problem is not seen to be overcome easily. The US Federal Court, in Vanishing Premium Insurance cases, provided:

[t]hough there are issues common to the members of the proposed class, including in particular the actions and state of mind of [the insurer] in pursuing the vanishing premium marketing strategy, these common questions are overshadowed by individualized issues such as the nature of the oral representations or disclosures made by the agent or broker at the point of sale, the nature of any questions asked by the consumer, the content of any written illustrations or disclosures given to the consumer, the degree of care exercised by the consumer in reviewing any written illustrations and the policy instrument, the portions of the offer that were attractive to the consumer, the degree of the consumer's financial sophistication and his or her understanding of the product. These individualized issues, which are essential to the determination of the claims of each class member, predominate over questions common to the class. ${ }^{59}$

Applying the criteria provided, eventually, PPI could not have been handled as class action.

56 Securities law became one of the hot topics in class damages actions as the court got more lenient about certification based on fraud-on-market theory. See Sherman, supra note 40, at 409.

57 This common sense is also challenged. For instance, the dissenting opinion of Halliburton case (Supra note 54) pointed out that investors did not believe that the current market price was reflecting available information properly but rather they did buy or sell stocks because they believed the share concerned was under- or over-valued.

58 In relation to this matter, suitability principle in itself presupposes that each investor is all different in past experience, attitude towards risk, wealth status or knowledge in investment. See, for instance, Chapter 9 of Conduct of Business Sourcebook, one of the FCA rules, as to suitability principle. Hence, recommendation of a certain securities may be suitable to some consumers while not suitable to others.

59 Cohn v. Mass. Mut. Life Ins. Co., 189 F.R.D. 209, 218 (1999). 


\section{B. A Lenient Criterion on Commonality under Canadian and Australian Rules}

Canada and Australia are, unlike America, more lenient in requirements of optout class action than the US. Under the rules of both jurisdictions, it is sufficient that claims have common grounds and they do not have to predominate individual issues. $^{6061}$

This liberal approach is dubious. Judgment in an opt-out class action entitles all members of the certified group to recover their damages as long as they do not declare exclusion from the certified group. Hence, the liberal approach may grant a windfall profit to any group member with more important individual issues. ${ }^{62}$ For this reason, relieving the requirement of commonality does not seem to fit well with concept of opt-out class action itself. ${ }^{63}$

In practice, under the liberal approach, only a slight commonality does not seem to guarantee continuance of opt-out class actions. The judges still have a discretion to conclude on whether a class action is a superior means to settle the disputes in a collective way. ${ }^{64}$ If the common issue is minor and overwhelmed by individual issues, it is not reasonable to deal with the matter in a class action. Accordingly, mis-selling cases are not easy to be handled in opt-out class action even under the lax rules. Ontario state courts, in Mutual Life Assurance Co. of Canada case, decertified a misselling class action on the following grounds:

The issue is not with respect to the use of illustrations or the systematic marketing of "premium offset" policies by the insurance companies, but rather, some individual complaints by some clients about the sales approaches of some agents. Many tens of thousands of policies were sold by hundreds of agents, but a relatively small number of purchasers complained about the representations allegedly made to them by agents at the time of sale; These transactions do not

60 Supra note 40 , at 430 .

61 For instance, Section 4 of Class Proceeding Act of British Columbia, one of the Canadian states, expressly states that class action can be certified if "the claims of the class members raise common issues, whether or not those common issues predominate over issues affecting only individual members."

62 N. Georgakopoulos, Frauds, Markets, and Fraud-on-the-Market: The Tortured Transition of Justifiable Reliance from Deceit to Securities Fraud, 49 U. Miami L. Rev. 712 (1995).

63 The predominance requirement is a mechanism to guarantee that "proposed classes are sufficiently cohesive to warrant adjudication by representation." See E. Sherman, American Class Actions: Significant Features and Developing Alternatives in Foreign Legal Systems, 215 F.R.D. 140-1 (2003), available at https://www.casemine.com/judgement/ us/5914b852add7b049347846ea.

64 Supra note 40, at 426. 
present common issues but, rather, individual representations. ${ }^{65}$

If the PPI scandal is handled in opt-out class action, the court could conclude on whether the selling process of a certain financial institutions is wrongful without considering specific facts of individual consumers. This will not be different from assessing on common factors in 'vacuum. ${ }^{96}$ The class action judgment declaring the defendant's misconduct at general level does not seem to be much helpful. Under Canadian or Australian rules, this judgement will be followed by a notification to each member of the certified group that s/he can submit claim forms asking assessment of individual facts. ${ }^{67}$ This procedure is out of the definition of "optout" system where members of certified group can be remedied without further legal action. If the court faces numerous individual claims following the class action judgment, this would be far from efficient collective redress.

\section{Applicability of Regulatory Intervention in Other Jurisdictions}

The regulator could deal with the PPI scandal in a collective way by ordering financial institutions to investigate individual aspects of the dispute. The regulatory intervention system showed sufficient efficiency by dealing with total 18.4 million mis-selling cases. It was more just and equitable in the sense that financial institutions which were liable to the scandal were asked to devote time and pecuniary costs themselves for individual investigations. If courts had faced such numerous PPI claims, they would seize huge public resources of court for proceeding those trials.

There might be some points to consider in relation to applicability of the regulatory intervention system to other jurisdictions. The regulator's intervention in restitution, compensation of damages or other monetary reliefs in relation to

65 Williams v. Mutual Life Assurance Co. of Canada, 2001 CarswellOnt 4449, 11 (Can. Ont. Div. Ct.) (WL).

66 FindLaw Attorney Writers, Canadian Class Action Law: A Flawed Model for European Class Actions, available at https:/corporate.findlaw.com/litigation-disputes/canadian-class-action-law-a-flawed-model-for-european-class.html.

67 Supra note 40 , at 417. 
breach of finance regulation is also found in the US, ${ }^{68}$ Canada, $^{69}$ Australia, ${ }^{70}$ Hong Kong $^{71}$ and Singapore. ${ }^{72}$ However, the regulatory civil enforcement is not universal. Such legislation is not easily found in civil jurisdictions. This seems to be related to legal doctrine in civil jurisdictions that government institutions including regulators should not intervene in civil matters like compensation of damages.

Nevertheless, the regulatory-led system is the only realistically viable option to collective redress at least in mis-selling cases. Also, collective redress is needed most for mis-selling of financial instruments because it is characterized by numerous victims with small losses. Furthermore, action of regulator as agent of aggrieved civil parties is not necessarily impossible in civil jurisdiction as shown by some Scandinavian countries' examples. Finland, Denmark and Norway permit class action brought by a government agency (Consumer Ombudsman) on behalf of consumers in finance or other areas. ${ }^{73}$

In case that the regulator-led collective redress system is adopted in other jurisdictions, this does not mean all factors concerned need to be imitated. Many of the aspects shown in the process is unique to the British financial regulation. The first trait is so-called Principle-based regulation. In this idea, "the focus is on setting out the purposive 'what' that needs to be achieved (in the retail context this is typically a particular outcome for a consumer), not the "how'." ${ }^{74}$ In so doing, FCA tries to use the expert knowledge and experience held by regulated parties to achieve its own regulatory goals. ${ }^{75}$ However, this idea might not be justified in civil jurisdictions where only descriptive and detailed rules are taken as justified as regulatory norms. ${ }^{76}$

68 The US CFPB, even though not based on this power, made agreements with financial institutions on reliefs for those aggrieved parties in relation to mis-selling of credit card add-on products. See CFPB Releases Report on Consumer Credit Card Market, available at https://www.jdsupra.com/legalnews/cfpb-releases-report-on-consumer-credit-68283.

69 Poonam Puri, Securities Litigation and Enforcement: The Canadian Perspective, 37 Brook. J. InT'L. L. 991 (2012).

70 Securities and Investments Commission Act $2001 \mathrm{~s} 50$. This power is not necessarily intended for collective redress, but can be used when it was highly likely for consumers to win the proceedings without sufficient financial resources to perform litigation. See J. Bird, ASIC's Role as Intervener: When Should the Regulator Intervene in Private Litigation?, 28 COMPANY \& SEC. L. J. 460 (2010), available at https://papers.ssrn.com/sol3/papers.cfm?abstract_id=1950464.

71 Ying Hu, The role of public enforcement in investor compensation: A Hong Kong perspective, 46(3) Common L. WORLd Rev. 217-8 (2017).

72 Securities and Futures Act $\S 324$ (Sing.).

73 See generally C. Hodges, Collective Redress in Europe: The New Model, Crv. Just. Q. (2010), available at https:// papers.ssrn.com/sol3/papers.cfm?abstract_id=1551985.

74 Supra note 2, at 50.

75 R. David, D. Awrey \& W. Blair, Between Law and Markets: Is There a Role for Culture and Ethics in Financial Regulation (Oct. 5, 2012), available at https://works.bepress.com/robert_david/1.

76 R. Veil, Enforcement of Capital Markets Law in Europe - Observations from a Civil Law Country, 11 Eur. Bus. ORGAN L. Rev. 414-5 (2010). 
The second part is the regulator's strong power. Especially, FCA's discretionary rule-making power is advantageous in adapting to rapid changes of financial market. ${ }^{77}$ However, the regulator's rule-making power should be limited to delegation of parliamentary legislation in civil jurisdictions. Accordingly, it is not expected in civil jurisdictions that the regulator, after considering all relevant factors, can exercise its wide discretion with maximum flexibility as FCA did in PPI saga. Hence, the scope and content of regulator's power should be more clearly delineated by parliament legislation. ${ }^{78}$

\section{Conclusion}

Under the PPI resolution process, the regulator set basic common principles and each concerned financial institution performed individual investigation and redress. Separation of collective and individual nature of the dispute appeared to be a key factor in this system. This basic structure is worthy of considering when designing of collective redress of mis-selling cases in other jurisdictions as well, even though all of the British factors of the process need not be imitated.

If the regulator-led approach is not adopted, two-stage actions can be the next alternative. Under the German Model Case Act, a kind of opt-in system, common issues are handled in "model proceeding" of higher court, which is followed by lower courts' multiple judgement on individual issues. ${ }^{79}$ Canadian and Australian opt-out class action also envisages the structure of two-stage action. ${ }^{80}$ Alleviating requirement of predominance opens up the way for handling mass mis-selling cases. However, the scope of relief and the level of deterrence effect inevitably would be limited.

77 Id. at $416-7$.

78 Id. at 416.

79 For brief introduction on German Model Proceedings Act, see M. Hilgard \& J. Kraayvanger, Class Actions and Mass Actions in Germany, Litigation Committee Newsletter (Sept., 2007), available at https://www.mayerbrown.com/ public_docs/Class_Actions_Mass_Actions_Germany.pdf.

$80 \quad$ Supra note 76. 